\title{
An Enemy Within Our Midst: Distinguishing Combatants from Civilians in the War Against Terrorism"
}

In any civilized society the most important task is achieving a proper balance between freedom and order.

-Chief Justice William Rehnquist ${ }^{1}$

\section{INTRODUCTION}

On September 10, 2001, Ali Saleh Kahlah al-Marri entered the United States to further a pledge he had made to Osama Bin Laden. ${ }^{2}$ According to the Director of the Joint Intelligence Task Force for Combating Terrorism, ${ }^{3}$ al-Marri first met Bin Laden in the summer of 2001 upon the urging of Khalid Sheikh Muhammed, the mastermind behind the attacks on September 11. ${ }^{4}$ Previously trained in the use of poisons at an al Qaeda camp and armed with an undergraduate degree from a respectable American university, ${ }^{5}$ al-Marri seemed perfectly

* Christina D. Elmore. J.D. candidate 2009, University of Kansas School of Law; B.A. 2006, William Jewell College. I would like to thank Professor David Gottlieb, Dr. Rein Staal, Adam Davis, and Carol Toland for their thoughts and comments on drafts. I would also like to thank my fiancé, Mike, for his love and support.

1. William H. Rehnquist, All the Laws But One: Civil Liberties in Wartime 222 (1998).

2. Declaration of Mr. Jeffrey N. Rapp, Director, Joint Intelligence Task Force for Combating Terrorism at 4, al-Marri ex rel. Berman v. Wright (al-Marri I), 443 F. Supp. 2d 774 (D.S.C. 2006) (No. 2:04-2257-HFF) [hereinafter Rapp Declaration], available at http://www.washingtonpost.com /wp-srv/nation/documents/jeffreyrapp_document.pdf.

3. The Rapp Declaration served as the basis for the government's allegations when al-Marri petitioned for a writ of habeas corpus. Al-Marri I, 443 F. Supp. $2 \mathrm{~d}$ at 780, rev'd en banc per curiam sub nom. al-Marri v. Pucciarelli, 534 F.3d 213 (4th Cir. 2008). Although the allegations against alMarri have yet to be proven in a court of law, al-Marri refused to present evidence to support his claim that he did not qualify for "enemy combatant" status. Id. at 784. The Fourth Circuit panel, rehearing al-Marri's petition on appeal, decided the case "assuming the truth of the Government's allegations." Al-Marri v. Wright (al-Marri II), 487 F.3d 160, 164 (4th Cir. 2007), vacated en banc per curiam sub nom. Pucciarelli, 534 F.3d 213. Likewise, the plurality of the en banc court issued the per curiam opinion on the assumption that the government's allegations were true. Pucciarelli (al-Marri III), 534 F.3d at 216.

4. Rapp Declaration, supra note 2 , at 5.

5. Id. Officials in the Justice Department explained after al-Marri's classification as an enemy combatant that he was alleged by another al Qaeda member in detention to have been trained in the use of poisons. Al Qaeda Suspect Declared 'Enemy Combatant,' CNN, June 24, 2003, 
qualified for the tasks Bin Laden had in mind: espionage and sabotage. At the meeting with Bin Laden, al-Marri agreed to move to the United States to act as a "sleeper agent." ${ }^{\text {B }}$ Bin Laden instructed al-Marri to enter the United States before September 11, 2001, or failing this, to cancel his plans and travel to Pakistan. ${ }^{7}$ Once in the United States, al-Marri was to explore the possibility of hacking into the main-frame computers of banks in order to sabotage U.S. banking records and thereby damage the U.S. economy. ${ }^{8}$

When FBI agents questioned al-Marri pursuant to a material witness warrant in December 2001, they uncovered on his laptop numerous files and bookmarked Internet sites relating to dangerous chemicals and poisons, including cyanides used in the manufacture of chemical weapons. ${ }^{9}$ The agents also found several computer programs used by hackers, lectures by Bin Laden regarding the importance of jihad and martyrdom, photographs of the September 11 attacks, and a cartoon image of a plane flying toward the World Trade Center. ${ }^{10}$ After receiving additional information regarding al-Marri's attempted contacts with al Qaeda, ${ }^{11}$ President Bush declared him an enemy combatant and al-Marri was transferred to a military brig in South Carolina. ${ }^{12}$ Upon a petition for a writ of habeas corpus, a panel of the Fourth Circuit determined that al-Marri, although a "grave threat" to the security of the United States, ${ }^{13}$ did not qualify as an "enemy combatant" as he had

http://www.cnn.com/2003/LAW/06/23/qatar.combatant/. Al-Marri allegedly trained at the camp for fifteen to nineteen months between 1996 and 1998. Rapp Declaration, supra note 2, at 5.

6. Rapp Declaration, supra note 2, at 5 .

7. Id. at 6 .

8. Id. Al Qaeda has remained interested in sabotaging the U.S. economy. See E. Alshech, 'The Battle... Is Economic Rather than Military'-An Economically Oriented Concept of Jihad Emerges in Islamist Discourse, MEMRI: THE MIDDle EAST MEDIA RESEARCH InSTITUTE, Sept. 11, 2007, http://memri.org/bin/opener.cgi?Page=archives\&ID=IA38707.

9. Rapp Declaration, supra note 2, at 7-8.

10. Id. at $10-11$.

11. While in the United States, al-Marri allegedly attempted to contact Khalid Sheikh Muhammed and Mustafa Ahmed Al-Hawsawi, al Qaeda members providing logistical support for the attacks on September 11, 2001. Id. at 8-9, 11-12.

12. Id. at 2. See also Al Qaeda Suspect Declared 'Enemy Combatant,' supra note 5 (discussing the Justice Department's explanation of al-Marri's classification). President Bush announced that alMarri had "engaged in conduct that constituted hostile and war-like acts, including conduct in preparation for acts of international terrorism." Id. The information obtained by the government indicated that al-Marri, although trained in the use of poisons, had not yet been ordered to carry out a biological or chemical attack in the United States. Id.

13. The majority stated "[i]f the Government's allegations are true, and we assume they are for present purposes, al-Marri... is a dangerous enemy of this nation who has committed serious crimes and associated with a secret enemy organization that has engaged in hostilities against us." Al-Marri II, 487 F.3d 160, 189 (4th Cir. 2007), vacated en banc per curiam sub nom. al-Marri III, 534 F.3d 213 (4th Cir. 2008). 
neither engaged in battle in Afghanistan nor affiliated with a territorial state. $^{14}$ Although individuals entering enemy territory to engage in espionage have traditionally qualified as unlawful enemy combatants, ${ }^{15}$ the panel refused to extend law of war principles, such as combatant status, to members of non-state terrorist organizations. On appeal, a plurality of the en banc court held that the government's allegations, if true, sufficed to detain al-Marri as an enemy combatant. ${ }^{16}$

The al-Marri decisions present grave and pressing questions regarding the appropriate limits of governmental power to detain suspected terrorists within our borders. Since September 11, 2001, hundreds have been detained in military prisons - held without charge regardless of their citizenship or place of capture-pursuant to an executive determination that they qualify as "enemy combatants." 17 Although the "enemy combatant" label therefore carries serious implications, the term still has no definitive parameters in the context of the fight against terrorism. Traditionally, a "combatant" has referred to a soldier, bearing arms in the name of a warring state. ${ }^{18}$ However, the executive and legislative branches have adopted definitions of an "enemy combatant" encompassing all persons who affiliate with and provide support to al Qaeda, regardless of whether they are found upon a battlefield. ${ }^{19}$ This approach recognizes the atrocities of September 11 as acts of war by expanding the traditional notion of the "enemy" to encompass non-state organizations. Such broad military reach into matters previously considered to be within the civilian domain ${ }^{20}$

14. Id. at 183 .

15. See Ex parte Quirin, 317 U.S. 1, 7-8, 15 (1942) (holding that German saboteurs became unlawful combatants upon entering into the United States without uniform, in violation of the laws of war).

16. Al-Marri III, 534 F.3d at 216.

17. Joseph P. "Dutch" Bialke, Al-Qaeda \& Taliban Unlawful Combatant Detainees, Unlawful Belligerency, and the International Laws of Armed Conflict, 55 A.F. L. REV. 1, 1 (2004). In Hamdi v. Rumsfeld, the Supreme Court upheld the executive's power to militarily detain those qualifying as "enemy combatants." 542 U.S. 507, 518 (2004).

18. PRELIMINARY REPORT OF THE AMERICAN BAR ASSOCIATION TASK FORCE ON TREATMENT OF ENEMY COMBATANTS (2002), at 8, available at http://www.abanet.org/leadership/enemy_ combatants.pdf.

19. Military Commissions Act of 2006, Pub. L. No. 109-366, 120 Stat. 2600 (codified in scattered sections of $10,18,28$, and 42 U.S.C.). Various definitions have been proposed through legislative bills since the attacks on September 11, 2001. For example, the Detention of Enemy Combatants Act sought to authorize the detention as an "enemy combatant" of any individual who was "a member of al Qaeda, or knowingly cooperated with a member of al Qaeda in the planning, authorizing, committing, aiding, or abetting of one or more terrorist acts against the United States." Detention of Enemy Combatants Act, H.R. 1076, 109th Cong. § 3(a) (2005).

20. Thomas Crocker, Still Waiting for the Barbarians: What is New about Post-September 11 Exceptionalism?, 19 LAW \& LITERATURE 303, 318-19 (2007). 
significantly threatens several essential civil liberties. ${ }^{21}$ Yet rigid adherence to traditional, state-based conceptions of warfare seems to be an unsatisfactory response to the security risk posed by modern transnational terrorist organizations as well.

This Comment addresses the proper parameters for the term "enemy combatant" in an age in which warfare may no longer be considered to occur only between states. It concludes that the term "enemy combatant" should encompass al Qaeda operatives actively engaged in or preparing for hostile activity within the United States, regardless of their citizenship. To support this claim, it will provide background information on the term "enemy combatant," including its historical roots in American jurisprudence, its current use by the executive, legislative and judicial branches, and its status under the international treaties and agreements constituting the laws of war. It will then address the rationales for expanding the traditional notion of a "combatant" to encompass suspected terrorists - particularly the enormous security risks posed by such individuals and the clear intent of Congress to authorize the use of force against a non-state organization.

It will then consider the laws of war and, more specifically, the historical purposes for distinguishing combatants from civilians and how states have traditionally treated hostile civilians during conflicts. With the law of war as a guidepost in determining combatant status, it will propose a definition successfully balancing the executive's security concerns with the need to prevent governmental encroachment upon cherished civil liberties. Under the proposed definition, an "enemy combatant" includes:

(a) An individual who qualifies for prisoner of war status under the Third Geneva Convention; or

(b) An individual who does not qualify for prisoner of war status under the Third Geneva Convention but who

1. Is affiliated with a state or organization with which the United States is engaged in a recognized armed conflict;

2. Engages in, aids and abets, or prepares to commit hostile acts against the United States or its co-belligerents; and

3. Acts with the intent thereby to harm the nation, its civilians, its economy, or its national security.

21. See Robert Chesney \& Jack Goldsmith, Terrorism and the Convergence of Criminal and Military Detention Models, 60 STAN. L. REV. 1079, 1081 (2008) (discussing the differences in procedural protections and burdens of proof between the military detention model and the criminal model). 
The Comment will conclude by describing the precise aspects of the proposed definition that comport with due process requirements and protect fundamental rights.

\section{BACKGROUND}

\section{A. The Enemy Inside: The Threat Posed by Al Qaeda Agents Within the United States}

Al Qaeda remains the most serious terrorist threat the United States faces. ${ }^{22}$ It is believed that al Qaeda still attempts to infiltrate operatives into the United States ${ }^{23}$ and will intensify its efforts to do so over the next few years. ${ }^{24}$ Indeed, al Qaeda has warned that muhajideen have successfully infiltrated our borders in preparation for another attack. ${ }^{25}$ The organization's successful efforts to advance its ideology have kept the FBI busy foiling attempted terrorist plots on our homeland. ${ }^{26} \mathrm{Al}$ Qaeda remains highly active in allied nations as well, demonstrating the enduring necessity of preventive action to reduce the likelihood of another terrorist attack. ${ }^{27}$

22. NATIONAL INTELligenCE COUNCIL, NATIONAL INTELLIGENCE Estimate: The TERRORIST THREAT TO THE US HOMELAND (2007), available at http://www.dni.gov/press_releases/20070717 release.pdf.

23. Threat Assessment: Statement Before the Senate Select Committee on Intelligence, 110th Cong. (2007) [hereinafter Mueller statement] (statement of Robert S. Mueller, III, Director, Federal Bureau of Investigation), available at http://www.fbi.gov/congress/congress07/mueller011107.htm.

24. NATIONAL INTELLIGENCE COUNCIL, supra note 22.

25. BBC News, Text: 'Bin-Laden tape,' http://news.bbc.co.uk/2/hi/middle_east/4628932.stm (last visited Aug. 26, 2008). See also CNN, Al-Zawahiri: Bush the 'Butcher of Washington,' http://www.cnn.com/2006/WORLD/asiapcf/01/30/zawahiri.transcript/ (last visited Aug. 26, 2008).

26. See Mueller statement, supra note 23 (describing recent plots against John F. Kennedy International Airport and Fort Dix, N.J., organized by "homegrown" terrorists). For more information regarding al Qaeda's efforts to advance its ideology, see generally Combating Al Qaeda and Militant Jihadists: Statement before the House Armed Services Committee, Subcommittee on Terrorism, Unconventional Threats and Capabilities, 109th Cong. (2006) [hereinafter Hoffman statement] (statement of Bruce Hoffman, Chair, Counterterrorism and Counterinsurgency, The RAND Corp.), available at http://www.rand.org/pubs/testimonies/2006/RAND_CT255.pdf.

27. According to the Director of the British Security Service, the United Kingdom in early 2007 was tracking 1600 people involved in at least 200 networks actively plotting terrorist attacks against targets in Britain. As of November 2006, Britain was tracking at least thirty plots, many of which were "linked to al Qaeda in Pakistan and using British-born foot soldiers living in the United Kingdom in its attack planning." Mueller statement, supra note 23. 


\section{B. The Executive Argument and the Legal Ramifications of "Enemy Combatant" Status}

In immediate response to the attacks of September 11, Congress authorized the President to

use all necessary and appropriate force against those nations, organizations or persons he determines planned, authorized, committed, or aided the terrorist attacks that occurred on September 11, 2001, or harbored such organizations or persons, in order to prevent any future acts of international terrorism against the United States by such nations, organizations or persons. ${ }^{28}$

The executive branch asserted that this broad grant of authority in the Authorization for the Use of Military Force (AUMF) authorized not only the initiation of warfare in Afghanistan but also the detainment of "enemy combatants" captured as part of the "global war on terror." 29 The executive has also maintained that the President has inherent constitutional authority to do so. ${ }^{30}$

In Hamdi v. Rumsfeld, the Supreme Court upheld the executive's assertion that the AUMF granted the President the power to detain "enemy combatants" as a fundamental incident of the "necessary and appropriate force" authorized. ${ }^{31}$ Hamdi, an American citizen, surrendered to U.S. troops while fighting alongside members of the Taliban in Afghanistan. ${ }^{32}$ The Court concluded that individuals fighting alongside the Taliban in Afghanistan (a traditional battlefield) clearly fall within the category of individuals Congress sought to target under the

28. Authorization for Use of Military Force, S.J. Res. 23, 107th Cong., 50 U.S.C. $§ 1541$ (2001).

29. On November 13, 2001, the President issued an executive order, pursuant to the power granted to him by the AUMF, permitting the detention and trial by military commission of al Qaeda members, terrorists or suspected terrorists, and any who harbor them. Detention, Treatment, and Trial of Certain Non-Citizens in the War Against Terrorism, 66 Fed. Reg. 57,833 (Nov. 13, 2001). See also Hamdi v. Rumsfeld, 542 U.S. 507, 517 (2004) (recognizing the President's authority to detain "enemy combatants" pursuant to the AUMF).

30. Al-Marri II, 487 F.3d 160, 177 (4th Cir. 2007), vacated en banc per curiam sub nom. alMarri III, 534 F.3d 213 (4th Cir. 2008). Whether the President has such inherent authority remains a contested issue, especially in regards to the detainment of U.S. citizens. See, e.g., Stephen I. Vladeck, The Detention Power, 22 YALE L. \& POL'Y ReV. 153, 155 (2004) (arguing that the President does not have inherent authority to detain).

31. Hamdi, 542 U.S. at 518-19.

32. Id. The military initially detained Hamdi in Afghanistan but then transferred him to the Guantánamo Naval Base in January 2002. Id. at 510. In April 2002, the military discovered Hamdi's citizenship and transferred him to a naval brig in South Carolina. Id. 
AUMF. ${ }^{33}$ Because the Court recognized that the AUMF provides the President with statutory authority to detain "enemy combatants," it did not address whether the President has inherent constitutional authority to do so. ${ }^{34}$

\section{American Citizens Aiding the Enemy: Wartime Decisions That Define the Parameters of the Debate}

\section{The Enemy Combatant Label Emerges: Ex Parte Quirin}

The phrase "enemy combatant" stems from a decision by the United States Supreme Court in the midst of World War II. ${ }^{35}$ On June 13 and 17, 1942, during "the hours of darkness," eight individuals exited German submarines positioned off the coast of the United States and went ashore. ${ }^{36}$ They discarded the German infantry uniforms they were wearing and buried them, along with explosives, fuses, and incendiary and timing devices. ${ }^{37}$ They entered New York City and Jacksonville, Florida, in two separate groups, wearing civilian attire. ${ }^{38}$ Soon thereafter, they were taken into custody by the FBI. ${ }^{39}$ Each had received instructions "from an officer of the German High Command to destroy war industries and war facilities in the United States." $" 40$ Each had been trained at a sabotage school in Berlin prior to arrival in the United States. ${ }^{41}$ One was a citizen of the United States. ${ }^{42}$

On July 2, 1942, the President proclaimed:

[A]ll persons who are subjects, citizens or residents of any nation at war with the United States or who give obedience to or act under the direction of any such nation, and who during time of war enter or attempt to enter the United States through coastal or boundary defenses, and are charged with committing or attempting or preparing to commit

33. Id. at 518

34. Id. at $516-17$.

35. Joanna Woolman, The Legal Origins of the Term "Enemy Combatant" Do Not Support its Present Day Use, 7 J.L. \& Soc. Challenges 145, 147 (2005).

36. Ex parte Quirin, 317 U.S. 1, 21 (1942). For a more detailed discussion of the case, see Louis Fisher, Military Tribunals: the Quirin Precedent, CRS RePort For Congress (2002), available at http://digital.library.unt.edu/govdocs/crs/permalink/meta-crs-2383:1.

37. Ex parte Quirin, 317 U.S. at 21.

38. Id.

39. Id.

40. $I d$.

41. Id.

42. Id. at 20 
sabotage, espionage, hostile or warlike acts, or violations of the law of war [would be subject to] military tribunals.

The eight saboteurs were therefore taken into military custody. ${ }^{44}$ The next day, they were charged with violating the laws of war, spying, and conspiring to commit the aforementioned offenses. ${ }^{45}$ They petitioned for a writ of habeas corpus and the Supreme Court upheld the lawfulness of their detention and trial by military commission. The Court distinguished between lawful and unlawful combatants, noting that while lawful combatants are to be classified as prisoners of war, subject to capture and detention, unlawful combatants are additionally "subject to trial and punishment by military tribunals for acts which render their belligerency unlawful." ${ }^{46}$ The Court provided the following examples of when an individual could properly be detained as an unprivileged belligerent: when a spy "secretly and without uniform passes the military lines of a belligerent in time of war, seeking to gather information and communicate it to the enemy," or when "an enemy combatant who without uniform comes secretly through the lines for the purpose of waging war by destruction of life or property."

The Court in Ex parte Quirin used several terms in referring to the petitioners, such as "unlawful combatants," "enemy combatants," and "enemy belligerents." It has been argued that the interchangeable use of such terms and the nature of the conflict at issue demonstrate that the Court intended the phrase "enemy combatant" to apply only to soldiers who had violated the laws of war. ${ }^{49}$ Indeed, the Quirin Court did not "distinguish between enemy soldiers who forfeit the right to be treated as prisoners of war by failing to distinguish themselves as belligerents ... and civilians who commit hostile acts during war without having the right to participate in combat." ${ }^{50}$ Although the executive has relied upon

43. Id. at $22-23$.

44. Id. at 23 .

45. Id.

46. Id. at 31 .

47. $I d$.

48. Woolman, supra note 35 , at 148.

49. Id.

50. Jennifer K. Elsea, Detention of American Citizens as Enemy Combatants, CRS REPORT FOR CONGRESS 12 (2005), available at http:/digital.library.unt.edu/govdocs/crs/permalink /meta-crs-6142:1. Later decisions of the Supreme Court applied the terms "enemy combatant" and "unlawful combatant" to uniformed soldiers who had violated the laws of war. See, e.g., In re Yamashita, 327 U.S. 1, 17-18 (1946) (authorizing the use of a military commission to prosecute the war crimes of a Japanese General). 
Quirin to justify the military detention of suspected terrorists, the intended scope of the decision remains uncertain. ${ }^{51}$

\section{Ex parte Milligan}

Ex parte Milligan, a famous decision from the Civil War era, has shaped the vigorous debate regarding the proper treatment of al Qaeda affiliates within the United States. ${ }^{52}$ On the basis of an executive order, Milligan was arrested and tried before a military commission for conspiracy, inciting insurrection, aiding the rebels, and violating the laws of war. ${ }^{53}$ Milligan was alleged to have been a member of the Sons of Liberty, a secret society affiliated with the Confederacy that advocated governmental overthrow. ${ }^{54}$ Milligan argued that, as a resident of Indiana, he had never associated with a rebel state and thus could not have violated the laws of war. ${ }^{55}$ The Supreme Court held that Milligan was a civilian and therefore entitled to trial by jury unless the courts were inoperable. $^{56}$ If it would have been dangerous to leave him a free man because he had conspired against the government and incited rebellion, he should have been arrested and tried in the civilian courts. ${ }^{57}$

Several judges in the al-Marri decisions have emphasized the similarities between Milligan and alleged al Qaeda operatives, arguing that the decision in Milligan forecloses any possibility of treating nonstate actors unaffiliated with a recognized military as "combatants." Milligan has been distinguished by others as inapplicable to the present situation in that Milligan did not associate with a rebel state or otherwise take part in hostilities and, unlike the war against al Qaeda, Congress never sanctioned the use of force against the Sons of Liberty. ${ }^{59}$ Indeed,

51. Woolman, supra note 35 , at $147-49$

52. See al-Marri III, 534 F.3d 213, 230 (4th Cir. 2008) (Motz, J., concurring) (comparing alMarri to Milligan). The persuasiveness of Milligan has been called into question by the United States Supreme Court. See Hamdan v. Rumsfeld, 548 U.S. 557, 597 n.27 (2006) (cautioning against reliance upon decisions from the Civil War era), superseded by statute, Military Commissions Act of 2006, Pub. L. No. 109-366, 120 Stat. 2600 (codified in scattered sections of 10, 18, 28, and 42 U.S.C.), as recognized in Boumediene v. Bush, 128 S. Ct. 2229, 2234 (2008).

53. Ex parte Milligan, 71 U.S. 2, 6 (1866).

54. ELSEA, supra note 50, at 12.

55. Ex parte Milligan, 71 U.S. at 7-8.

56. Id. at 78 .

57. Id.

58. See al-Marri III, 534 F.3d 213, 230-31 (4th Cir. 2008) (Motz, J., concurring) (comparing al-Marri to Milligan).

59. Al-Marri II, 487 F.3d 160, 198 (4th Cir. 2007) (Hudson, J., dissenting), vacated en banc per curiam sub nom. al-Marri III, 534 F.3d 213; al-Marri III, 534 F.3d at 301 (Wilkinson, J., concurring in part and dissenting in part). 
the Supreme Court has recognized that Ex parte Quirin clarified the decision in Ex parte Milligan, ${ }^{60}$ leading some to the conclusion that Milligan is applicable only once it is determined that the individual cannot qualify as an enemy combatant. ${ }^{61}$

\section{The Status of Terrorist Organizations and Their Members Under the Laws of War}

The "laws of war," from which the federal courts seek guidance, ${ }^{62}$ consist primarily of the various international treaties addressing armed conflict as well as customary international law, built upon the customs and practices of states. ${ }^{63}$ The treaties relating to armed conflict consist of the 1907 Hague Convention Respecting the Laws and Customs of War on Land ("Hague Convention") and the 1949 Geneva Conventions and additional protocols. ${ }^{64}$ Essentially repeating the requirements set forth in the Hague Convention, the Geneva Conventions provide combatant immunity only in specified circumstances. ${ }^{65}$ Those who satisfy the

60. Hamdi v. Rumsfeld, 542 U.S. 507, 522 (2004).

61. See, e.g., al-Marri III, 534 F.3d at 301 (Wilkinson, J., concurring in part and dissenting in part) (discussing why Milligan is inapplicable to the determination of whether al-Marri qualifies as an enemy combatant).

62. See The Paquete Habana, 175 U.S. 677, 700 (1900) ("International law is part of our law, and must be ascertained and administered by the courts of justice of appropriate jurisdiction ....").

63. Michael A. Newton, Continuum Crimes: Military Jurisdiction Over Foreign Nationals Who Commit International Crimes, 153 MIL. L. REV. 1, 54 (1996).

64. Protocol Additional to the Geneva Conventions of 12 August 1949, and Relating to the Protection of Victims of International Armed Conflicts (Protocol I), June 8, 1977, 1125 U.N.T.S. 3 [hereinafter Protocol I]; Protocol Additional to the Geneva Conventions of 12 August 1949, and Relating to the Protection of Victims of Non-International Armed Conflicts (Protocol II), June 8, 1977, 1125 U.N.T.S. 609 [hereinafter Protocol II]; Geneva Convention Relative to the Treatment of Prisoners of War, Aug. 12, 1949, 6 U.S.T. 3316, 75 U.N.T.S. 135 [hereinafter Geneva Convention III]; Geneva Convention Relative to the Protection of Civilian Persons in Time of War, Aug. 12, 1949, 6 U.S.T. 3516, 75 U.N.T.S. 287 [hereinafter Geneva Convention IV]; Hague Convention: Laws and Customs of War on Land, ch. 1, art. 1, Oct. 18, 1907, 36 Stat. 2277, 205 Consol. T.S. 277.

65. Geneva Convention III, supra note 64 , art. 4. To qualify as a prisoner of war, the individual must have fallen into the power of the enemy and belong to one of six categories, including:

(1) Members of the armed forces of a Party to the conflict, [or] members of militias or volunteer corps forming part of such armed forces.

(2) Members of other militias and members of other volunteer corps, including those of organized resistance movements, belonging to a Party to the conflict... provided that such militias or volunteer corps ... fulfil the following conditions:

(a) that of being commanded by a person responsible for his subordinates;

(b) that of having a fixed distinctive sign recognizable at a distance;

(c) that of carrying arms openly;

(d) that of conducting their operations in accordance with the laws and customs of war. 
criteria are "lawful combatants," privileged to engage in hostilities without punishment for their actions. ${ }^{66}$ These individuals are entitled to prisoner of war status upon capture and may not be prosecuted for any hostile acts in conformity with the laws of war. ${ }^{67}$ If they have committed any violations of the laws of war (war crimes), they may be prosecuted for such acts by military commission. ${ }^{68}$

Although the Geneva Conventions do not define "unlawful combatants" or "unprivileged belligerents," it is widely understood by implication and tradition that combatants who violate the laws of war and individuals who engage in hostilities, but do not satisfy the Geneva Conventions' criteria for combatant privilege, are "unlawful combatants." 69 Unlawful combatants are not entitled to prisoner of war status and may be tried by military commissions for their actions. ${ }^{70}$ The commentary to the 1949 Geneva Convention implies that unlawful combatants may be detained even after hostilities have ended. ${ }^{71}$

The laws of war, therefore, clearly distinguish between lawful and unlawful belligerents. ${ }^{72}$ However, the military detainment of suspected terrorists post-September 11 has generated intense debate concerning the proper status and treatment of such individuals. ${ }^{73}$ The administration has taken the position that al Qaeda members and affiliates qualify as "unlawful combatants," and therefore are not entitled to the protections accorded lawful combatants under Convention III or to those accorded civilians under Convention IV. ${ }^{74}$ Individuals acting on behalf of terrorist organizations certainly cannot qualify as "prisoners of war," for they fail to satisfy the established criteria. ${ }^{75}$ However, the International

66. Knut Dörmann, The Legal Situation of "Unlawful/Unprivileged Combatants," 85 INT'L REV. RED CROSS 45, 45 (2003).

67. Id. See also Mark David 'Max' Maxwell \& Sean M. Watts, 'Unlawful Enemy Combatant': Status, Theory of Culpability, or Neither?, 5 J. INT'L CRIM. JUST. 19, 21 (2007).

68. See, e.g., In re Yamashita, 327 U.S. 1, 17 (1946) (upholding the authority of a military commission to prosecute a Japanese General for his failure to prevent Japanese troops from massacring thousands of civilians while stationed in the Philippines).

69. Dörmann, supra note 66, at 46; Peter Jan Honigsberg, Chasing "Enemy Combatants" and Circumventing International Law: A License for Sanctioned Abuse, 12 UCLA J. INT'L L. \& FOREIGN AFF. 1, 9 (2007).

70. See Woolman, supra note 35, at 161 (“'Unlawful combatants,' unlike lawful combatants, have traditionally been tried in front of military tribunals ....").

71. Id. at $161-62$.

72. See Dörmann, supra note 66 , at 46 .

73. See, e.g., Marco Sassòli, "Unlawful Combatants": The Law and Whether It Needs to be Revised, 97 AM. Soc'Y INT’L L. Proc. 196, 197-98 (2003).

74. Id. at 196.

75. Al Qaeda is not a signatory to the 1949 Geneva Conventions and its members therefore could not qualify as prisoners of war (lawful combatants) under Geneva Convention III. Douglas Hass, Note, Crafting Military Commissions Post-Hamdan: The Military Commissions Act of 2006, 
Committee of the Red Cross has taken the position that individuals not entitled to the protections accorded prisoners of war under Convention III necessarily fall within the ambit of Convention IV as civilians. ${ }^{76}$ The Commentary to Convention IV confirms this view:

Every person in enemy hands must have some status under international law; he is either a prisoner of war and, as such, covered by the Third Convention, a civilian covered by the Fourth Convention, or again, a member of the medical personnel of the armed forces.... There is no intermediate status; nobody in enemy hands can be outside the law.

Additional classification issues arise from the distinction between international armed conflicts and non-international armed conflicts. ${ }^{78}$ Although the law of international armed conflict distinguishes between lawful and unlawful combatants, the law of non-international armed conflict does not. ${ }^{79}$ Common Article 2 of the 1949 Geneva Conventions $^{80}$ and Article 1(4) of Protocol 1, signed in 1977, establish the various conflicts which may be deemed "international" in character. ${ }^{81}$ Only two forms of conflict could involve terrorist organizations: resistance to total or partial occupation and struggle for national liberation. $^{82}$ Neither would apply to the general conflict against al Qaeda's transnational network. ${ }^{83}$ The administration adamantly insists that the global nature of the war against al Qaeda qualifies it as an international armed conflict. ${ }^{84}$ However, the Supreme Court held in Hamdan v. Rumsfeld that the conflict against al Qaeda in Afghanistan is

82 IND. L.J. 1101, 1106-07 (2007). Moreover, al Qaeda affiliates refuse to comply with the laws of war and therefore would not satisfy the established criteria for combatant immunity. Id. at 1113-14.

76. Dörmann, supra note 66, at 49; Honigsberg, supra note 69, at 16.

77. Convention (IV) Relative to the Protection of Civilian Persons in Time of War, Aug. 12, 1949, art. 4 cmt., at 51 [hereinafter Geneva Conventions Commentary], available at http://www.icrc.org/ihl.nsf/com/380-600007?OpenDocument.

78. See, e.g., George H. Aldrich, The Taliban, Al Qaeda, and the Determination of Illegal Combatants, 96 AM. J. INT'L L. 891, 893 (2002) (discussing the implications of numerous states and nationalities being involved in terrorism and conflicts); Hass, supra note 75, at 1106-10 (discussing the debate over whether the conflict with al Qaeda qualifies as international or non-international).

79. Dörmann, supra note 66, at 47; Sassòli, supra note 73, at 197.

80. Geneva Convention III, supra note 64, art. 2.

81. Protocol I, supra note 64, art. 1(4).

82. Id.; Daphné Richemond, Transnational Terrorist Organizations and the Use of Force, 56 CATH. U. L. REV. 1001, 1014 (2007). Moreover, al Qaeda members refuse to comply with the laws of war and thus would not satisfy the established criteria for combatant immunity. Id.

83. The conflict with al Qaeda in particular geographic areas could, however, qualify as "international armed conflict" on the basis of struggle against occupation. For instance, al Qaeda operates on occupied territory in Iraq. Richemond, supra note 82, at 1014.

84. Sassòli, supra note 73, at 196. 
a non-international armed conflict, ${ }^{85}$ seemingly rejecting the administration's characterization of the war on a more global scale as well.

Common Article 3 of the 1949 Geneva Conventions and Protocol II govern non-international armed conflict. $^{86}$ Under Article 1(1) of Protocol II, a conflict may be deemed non-international in nature only if it satisfies certain criteria. ${ }^{87}$ In particular, the conflict must take place "in the territory of a [state] between its armed forces and dissident armed forces or other organized armed groups which, under responsible command, exercise such control over a part of [a state's] territory as to enable them to carry out sustained and concerted military operations." ${ }^{\prime 8}$ It seems problematic to apply this definition to various aspects of the war against al Qaeda. ${ }^{89}$ However, the Supreme Court in Hamdan v. Rumsfeld appeared to adopt the view that any conflict not qualifying as an international armed conflict should be considered a non-international armed conflict, governed by Common Article 3. ${ }^{90}$

\section{E. The Judicial and Congressional Response}

\section{Hamdi v. Rumsfeld}

In Hamdi v. Rumsfeld, the Supreme Court recognized the President's authority under the AUMF to detain an American citizen fighting alongside the Taliban in Afghanistan. ${ }^{91}$ The Court determined that Hamdi qualified as an "enemy combatant" because he was "part of or supporting forces hostile to the United States or coalition partners" in Afghanistan and "engaged in an armed conflict against the United States." 92 Recognizing the debate over the proper scope of the term "enemy combatant," the Court left to the lower courts the task of delineating its "permissible bounds." 93

\footnotetext{
85. Hamdan v. Rumsfeld, 548 U.S. 557, 628-29 (2006), superseded by statute, Military Commissions Act of 2006, Pub. L. No. 109-366, 120 Stat. 2600 (codified in scattered sections of 10, 18, 28, and 42 U.S.C.), as recognized in Boumediene v. Bush, 128 S. Ct. 2229, 2234 (2008).

86. Protocol II, supra note 64, art. 1(1); Geneva Convention IV, supra note 64, art. 3. The United States has not ratified the additional protocols. Honigsberg, supra note 69, at 17.

87. Protocol II, supra note 64, art. 1(1).

88. Id. (emphasis added).

89. See Richemond, supra note 82 , at 1015 .

90. Id. at $1017 \mathrm{n} .72$.

91. Hamdi v. Rumsfeld, 542 U.S. 507, 518 (2004).

92. Id. at 526

93. Id. at $522 \mathrm{n} .1$.
} 


\section{The Military Commissions Act of 2006}

In 2006, Congress enacted the Military Commissions Act (MCA) as a response to the Supreme Court's decision in Hamdan v. Rumsfeld. ${ }^{94}$ The MCA delineates between lawful and unlawful enemy combatants. A lawful enemy combatant is defined in accordance with the provisions set forth for prisoner of war classification in the Third Geneva Convention. ${ }^{95}$ An unlawful enemy combatant is defined as:

(i) A person who has engaged in hostilities or who has purposefully and materially supported hostilities against the United States or its cobelligerents who is not a lawful enemy combatant (including a person who is part of the Taliban, al Qaeda, or associated forces); or

(ii) A person who, before, on, or after the date of the enactment of the Military Commissions Act of 2006, has been determined to be an unlawful enemy combatant by a Combatant Status Review Tribunal or another competent tribunal established under the authority of the President or the Secretary of Defense. ${ }^{96}$

The MCA authorizes military commissions to try alien unlawful enemy combatants for any offenses therein or any violations of the law of war. ${ }^{97}$ It also amends the Uniform Code of Military Justice to provide military tribunals with jurisdiction over the offenses of "conspiracy" and "providing material support for terrorism." 98 It additionally purports to strip federal courts of jurisdiction to hear habeas petitions of alien enemy combatants; however, the Court has deemed this an unconstitutional attempt to suspend the writ. ${ }^{99}$

94. Hass, supra note 75, at 1102. See Hamdan v. Rumsfeld, 548 U.S. 557 (2006), superseded by statute, Military Commissions Act of 2006, Pub. L. No. 109-366, 120 Stat. 2600 (codified in scattered sections of 10, 18, 28, and 42 U.S.C.), as recognized in Boumediene v. Bush, 128 S. Ct. 2229, 2234 (2008)

95. See Military Commissions Act of 2006, 10 U.S.C. § 948a(2) (2006); Geneva Convention III, supra note 64, art. 4.

96. Military Commissions Act of 2006, § 948a(1).

97. Id. $\S 948 \mathrm{~b}(\mathrm{a}), 948 \mathrm{c}$.

98. Id. $\S 950 \mathrm{v}(\mathrm{b})(25),(28)$. But see Hamdan, 548 U.S. at 603-04 (refusing to recognize "conspiracy" as a violation of the laws of war).

99. Military Commissions Act of 2006, §950j(b); Boumediene, 128 S. Ct. at 2274. 


\section{The Sleeper Scenario: al-Marri v. Wright}

a. The Rapp Declaration

According to the information obtained by the government, al-Marri traveled to the United Arab Emirates after meeting with Bin Laden in the summer of 2001. ${ }^{100}$ Al Qaeda financier Mustafa Ahmed al-Hawsawi met him at the Dubai airport and provided him with $\$ 10,000$ to $\$ 13,000$ and an additional $\$ 3000$ to purchase a laptop. ${ }^{101}$ Al-Marri moved to Peoria, Illinois, purportedly to obtain a graduate degree in computer science at Bradley University. ${ }^{102} \mathrm{He}$ had not contacted the school about commencing his studies until July of 2001 and the school felt that he was in a rush to begin. ${ }^{103}$ Within a few months, al-Marri rarely attended classes and was failing his courses. ${ }^{104}$

At various times after September 11, al-Marri used calling cards to attempt to reach al-Hawsawi, who had provided logistical support for the September 11 attacks and assisted the hijackers in obtaining funds while in the U.S. ${ }^{105}$ Al-Marri had also established several e-mail accounts, some of which were later found to contain draft e-mail messages written to Khalid Sheikh Mohammed, mastermind behind the attacks on September $11 .^{106}$ The messages contained coded versions of al-Marri's cell phone number. ${ }^{107}$

Moreover, al-Marri had been conducting significant research during his time in Peoria on the use of dangerous chemicals. ${ }^{108}$ Several sites were found bookmarked, including links to the Occupational Safety and Health Administration (OSHA) homepage and to a website listing "Immediately Dangerous to Life and Health" chemical concentrations. ${ }^{109}$ Other websites visited included "The Manufacture of Hydrogen Cyanide," containing step-by-step instructions; "Cyanide Poisoning and Cyanide Antidotes"; and "Toxicity Profiles: Cyanides." According to

\footnotetext{
100. Rapp Declaration, supra note 2, at 5-6. Al-Marri allegedly traveled to the United Arab Emirates in August 2001. Id.

101. Id. at 6-7.

102. Id. at 5 .

103. Id.

104. Id.

105. Id. at 6,11 .

106. Id. at 8-9.

107. Id. at 9 .

108. Id. at 7-8.

109. $I d$. at 7 .

110. Id. at 7-8.
} 
the government, al-Marri's research was consistent with al Qaeda's known interest in the use of cyanides, particularly hydrogen cyanide. ${ }^{111}$

\section{b. The District Court Ruling}

A district court in South Carolina determined that the government's allegations against al-Marri sufficed to detain him as an enemy combatant. ${ }^{112}$ Although the district court observed that Hamdi addressed when an individual supports hostile forces in Afghanistan, it reasoned that the Supreme Court did not intend to limit Hamdi to traditional battlefield situations. ${ }^{113}$ Al-Marri could therefore remain detained on the basis of the government's allegations, as he had refused to offer evidence rebutting the allegations when offered the opportunity. ${ }^{114}$

\section{c. The Fourth Circuit Panel Opinion}

However, a majority of a Fourth Circuit panel determined that the military could not detain al-Marri. ${ }^{115}$ After concluding that the jurisdiction-stripping provision of the Military Commissions Act did not apply to al-Marri, ${ }^{116}$ the panel addressed two specific arguments regarding the President's authority to detain. First, the government asserted that the AUMF empowers the President to detain enemy combatants. ${ }^{117}$ Second, the government argued that, even if the AUMF could not be so construed, the President has the inherent constitutional authority to detain. ${ }^{118}$ Rather than address the "serious constitutional questions" such arguments purportedly raised, the majority of the panel

111. Id. at 7. Al Qaeda instructed its members on the use of hydrogen cyanide at training camps in Afghanistan. Id. at 8.

112. Al-Marri I, 443 F. Supp. 2d 774, 784 (2006), rev'd per curiam en banc sub nom. al-Marri III, 534 F.3d 213 (4th Cir. 2008).

113. See id. at 780 ("It is clear, then, that the term 'enemy combatant' is not limited to the definition used in Hamdi.").

114. Id. at 784

115. Al-Marri II, 487 F.3d 160, 184 (4th Cir. 2007), vacated en banc per curiam sub nom. alMarri III, 534 F.3d 213.

116. The MCA purports to strip the federal courts of jurisdiction to hear habeas petitions once an alien detainee has "been determined by the United States to have been properly detained as an enemy combatant or is awaiting such determination." Al-Marri II, 487 F.3d at 168 . The panel determined that this provision requires an initial decision, such as an executive order, as well as a subsequent determination of the propriety of the initial decision. Id. at 170. As no subsequent determination occurred and al-Marri was not awaiting it, the jurisdiction-stripping provision did not apply. Id. at $172-73$.

117. Id. at 174 .

118. Id. at 177 
determined that al-Marri could not be classified as an enemy combatant. ${ }^{119}$ Relying upon Ex parte Quirin and Ex parte Milligan, the court held that enemy combatant status "rests on an individual's affiliation during wartime with the "military arm of the enemy government." 120 As al-Marri had never stood alongside the Taliban, taken up arms in Afghanistan, or engaged in direct, armed hostilities against United States forces, the majority believed he could not qualify as an "enemy combatant."."121

\section{d. The Fourth Circuit En Banc Opinion}

On July 15, 2008, the Fourth Circuit, sitting en banc, issued a per curiam opinion addressing the authority of the executive to detain alMarri as an enemy combatant. ${ }^{122}$ It determined that the AUMF empowers the President to detain al-Marri as an enemy combatant, provided the government's allegations against al-Marri are true. ${ }^{123}$ However, the court also determined that al-Marri had "not been afforded sufficient process to challenge his designation as an enemy combatant." 124 The opinions of the judges were expressed in several separately written opinions.

In an opinion joined by three other judges, Judge Motz elucidated further upon her argument that al-Marri cannot qualify as an enemy combatant as he did not affiliate "with the armed forces of an enemy nation." 125 Judge Motz relied upon the purportedly narrow ruling in Hamdi as well as the legislative history of the AUMF in concluding that neither the Supreme Court nor Congress intended to permit the detention of those lawfully residing within the U.S. at the time of capture. ${ }^{126}$ Judge Motz pointed to the Patriot Act as conclusive evidence that Congress intended to treat alien suspected terrorists as criminals rather than combatants, subject to temporary administrative detention but not to

\footnotetext{
119. Id. at 178 .

120. Id. at 181 (quoting Ex parte Quirin, 317 U.S. 1, 37-38 (1942)). anywhere in the world.").

122. Al-Marri III, 534 F.3d 213 (4th Cir. 2008) (en banc) (per curiam).

123. Id. at 216

124. Id.

125. Id. at 230 (Motz, J., concurring)

126. Id. at $229,239-40$.
}

121. See id. at 183 ("[A]l-Marri is not alleged to have been part of a Taliban unit, not alleged to have stood alongside the Taliban or the armed forces of any other enemy nation, not alleged to have been on a battlefield during the war in Afghanistan, not alleged to have even been in Afghanistan during the armed conflict there, and not alleged to have engaged in combat with United States forces 
extended military confinement. ${ }^{127}$ After considering the international standards for combatant status, Judge Motz concluded that an individual may not be classified as an enemy combatant merely for engaging in criminal conduct. ${ }^{128}$

In a separate opinion, Judge Wilkinson strongly disagreed with the conclusion reached by Judge Motz, noting that while the broad language of the AUMF could present difficult issues for determining the permissibility of detaining certain categories of individuals, al-Marri's case "fits squarely within the bounds of the AUMF" because Congress enacted the AUMF in response to the targeting of U.S. civilians on American soil rather than upon a foreign battlefield. ${ }^{129}$ After critiquing the plurality approach as a violation of the "separation of powers" doctrine, Judge Wilkinson proposed a definition of "enemy combatant," understanding Hamdi as explicit authorization for the lower courts to engage in such an analysis. Judge Wilkinson set forth the following definition of an "enemy combatant" for purposes of the war against terrorism: an enemy combatant is one "who is (1) a member of (2) an organization or nation against whom Congress has declared war or authorized the use of military force" (3) "who knowingly plans or engages in conduct that harms or aims to harm persons or property for the purpose of furthering the military goals of an enemy nation or organization." 130

\section{ANALYSIS}

\section{A. The Traditional "Enemy Combatant" Concept Must be Broadened to} Encompass Al Qaeda Agents Engaging in or Preparing for Hostile Acts Within the United States

The attacks on September 11 ushered in a new age in warfare, an age in which the "enemy" may no longer be conceptualized in reference to a particular geographic region and distinctions between "civilians" and "combatants" blur. Al Qaeda's "soldiers" move through the shadows, blending into civilian society in anticipation of the moment of attack.

127. Id. at 248-49. Judge Wilkinson disagreed that the Patriot Act carries any relevance, noting that the two "have different spheres of operation," the Patriot Act being inapplicable until after it has been demonstrated that the individual does not qualify as an "enemy combatant." Id. at 301-02 (Wilkinson, J., concurring in part and dissenting in part).

128. Id. at 233, 235 (Motz, J., concurring).

129. Id. at 298, 300 (Wilkinson, J., concurring in part and dissenting in part).

130. Id. at 323-24. 
The traditional war paradigm, an antiquated state-based model, ${ }^{131}$ fails to provide an adequate response to such subversive activity. However, the United States is engaged in a war against al Qaeda - a war sanctioned by Congress. The treatment of suspected al Qaeda members within our borders must reflect these new realities.

\section{Al Qaeda Agents Acting Within the United States Create a Grave Security Risk}

No longer does it take an army of several thousand acting in concert to seriously threaten another nation's political sovereignty-modern technology has armed individual terrorists with the "power to bring a state to its knees." 132 Given the grave security risk presented by al Qaeda members actively working from within the United States, it is critical that the military be capable of detaining such individuals in order to prevent the recurrence of a large-scale terrorist attack. It makes little sense from a security standpoint to classify al Qaeda agents as "civilians," rather than "combatants," merely because they happened to be captured closer to their target. For instance, the panel opinion in $a l$ Marri II would have prevented the military detention of those directly responsible for the attacks on the World Trade Center. ${ }^{133}$ Such a result seems clearly at odds with the avowed intent of the government to prevent any future acts of international terrorism upon U.S. soil and fails to account for the modern realities of warfare. Although terrorism has always existed, modern terrorism has "emerged as a strategy of revolutionary struggle only in the period after World War II." ${ }^{\text {"134 }}$ Modern terrorists potentially have access to weapons of mass destruction and intentionally target civilian infrastructure, creating a limitless "battlefield." In addition, they purposely blend into civilian society and thereby render the traditional indicia of a "combatant," such as a uniform, "woefully unreflective of the risks ....".

Al Qaeda's militant and hierarchical nature compounds the threat in a manner inapplicable to "Islamic terrorism" generally. Al Qaeda has long considered itself at war with the United States, declaring so

131. See id. at 316; Richemond, supra note 82, at 1001.

132. Peter Berkowitz, Introduction, in TERRORISM, THE LAWS OF WAR, AND THE Constitution, at ix (Peter Berkowitz ed., 2005).

133. See al-Mari III, 534 F.3d at 297 (Wilkinson, J., concurring in part and dissenting in part).

134. Id. at 321 (quoting MichaEL WALZER, JUST AND UNJUST WARS 198 (3d ed. 2000)). Walzer defines such "modern terrorism" as "the random murder of innocent people." WALZER, supra, at 198.

135. Id. 
numerous times prior to the attacks on September $11 .^{136}$ It trains its "soldiers" at camps, allegedly circulating "military manuals" that describe such matters as the principles of military organization, security precautions for its "command centers" within targeted cities, the purchase and transport of weapons, the proper means of engaging in espionage, recruitment of foreign intelligence agents, methods of assassination, and methods of detonating explosives. ${ }^{137}$ Moreover, it is believed that al Qaeda retains important characteristics of an organized entity "with a central command and control structure," including a core leadership that coordinates attacks, surveillance, and planning operations. ${ }^{138}$ Indeed, al Qaeda's extensive structure and scope of operations makes it nearly indistinguishable from a de facto government:

[It] has a standing army; it has a treasury and a consistent source of revenue; it has a permanent civil service; it has an intelligence collection and analysis cadre; it even runs a rudimentary welfare program for its fighters, and their relatives and associates. It has a recognizable hierarchy of officials; it makes alliances with other states; it promulgates laws, which it enforces ruthlessly; it declares wars. ${ }^{139}$

\section{The United States Is “At War" With Al Qaeda}

The split of opinion in the Fourth Circuit over the proper treatment of al Qaeda affiliates captured within the United States is indicative of a weightier question regarding the ability of a sovereign nation to engage in "warfare" with a non-state actor such as al Qaeda. The position taken by Judge Motz reflects the view of commentators who have argued that the war against "terrorism" or particular transnational terrorist organizations (including al Qaeda) must be metaphorical only, similar to a war on drugs or a war on crime. ${ }^{140}$ The proffered rationale is that a

136. Osama bin Laden, Declaration of War Against the Americans Occupying the Land of the Two Holy Places, August 1996, http://www.pbs.org/newshour/terrorism/international/fatwa 1996.html; Osama bin Laden, Jihad Against Jews and Crusaders, Feb. 23, 1998, http://www.pbs.org/newshour/terrorism/international/fatwa_1998.html.

137. Al QAeda Training Manual, Military Studies in the JiHad Against the Tyrants, http://www.usdoj.gov/ag/manualpart1 1.pdf (last visited Aug. 27, 2008). The manual was found by the police in Manchester, England, during a search of an al Qaeda member's home. Id. at 1.

138. Hoffman statement, supra note 26; Mueller statement, supra note 23. For a description of al Qaeda's structure, see Jessica Erin Tannenbaum, Comment, Fighting the War on Terrorism with the Legal System: A Defense of Military Commissions, 11 AnN. SuRV. INT'L \& CoMP. L. 79, 83 (2005).

139. Al-Marri III, 534 F.3d at 300 (Wilkinson, J., concurring in part and dissenting in part) (citing PHILIP BoBbit, The SHIELD OF ACHILles 820 (2002)).

140. See, e.g., Joan Fitzpatrick, Jurisdiction of Military Commissions and the Ambiguous War on 
conflict with a terrorist organization could never rise to the level of "warfare," as a state of war can exist only between sovereign nations or within the context of an internal rebellion. ${ }^{141}$ However, Congress conferred full authority under the AUMF to prosecute a war against nontraditional actors. ${ }^{142}$ Moreover, treatment of the war domestically and internationally indicates a general acceptance of the idea that warfare may occur between states and non-state actors such as al Qaeda.

Congress chose to treat the attacks on September 11 as acts of war in enacting the AUMF. The statutory text itself indicates Congress's clear intent to engage military force against a non-state organization: the AUMF explicitly authorizes the use of force against "organizations" and "persons." "43 Moreover, the legislative history of the AUMF demonstrates that members of Congress were aware of the implications of a decision to authorize unconventional warfare. For instance, Senator Kohl noted that "the Senate has taken a somber step toward a new kind of war. Congress has resolved that military force may be necessary to end the scourge of terrorism."144

Indeed, the AUMF confers upon the President authority comparable to that provided in declared wars. ${ }^{145}$ Recent research by scholars Curtis A. Bradley and Jack L. Goldsmith demonstrates that a formal declaration of war is unnecessary to confer full authority to prosecute the war on terror and the AUMF's broad terms indeed provide such authority. ${ }^{146}$ Given that several undeclared wars occurred before ratification of the Constitution, the founders likely did not view a formal declaration as a constitutional requirement for the President to engage in hostilities. ${ }^{147}$ Moreover, historical practice has confirmed that Congress may fully empower the President to engage in war within the bounds of the

Terrorism, 96 AM. J. INT'L L. 345, 346-47 (2002) (describing the post-September 11 war as "metaphorical" because a state of war cannot exist between the United States and al Qaeda under international notions of warfare); Jordan J. Paust, Responding Lawfully to Al Qaeda, 56 CATH. U. L. REV. 759, 760-61 (2007) (arguing that the United States cannot be at war with al Qaeda under internationally accepted notions of warfare or armed conflict).

141. See Paust, supra note 140 at $760-61$.

142. Curtis A. Bradley \& Jack L. Goldsmith, Congressional Authorization and the War on Terrorism, 118 HARV. L. REV. 2047, 2066-71 (2005).

143. See al-Marri II, 487 F.3d 160, 196 (4th Cir. 2007) (Hudson, J., dissenting), vacated en banc per curium sub nom. al-Marri III, 534 F.3d 213.

144. 147 CONG. REC. 17,038 (2001) (statement of Sen. Kohl).

145. Bradley \& Goldsmith, supra note 142, at 2054.

146. Id. at 2058-62.

147. The numerous undeclared wars prior to the ratification of the Constitution led to a comment in the Federalist Papers that "the ceremony of a formal denunciation of war has of late fallen into disuse." Id. at 2058-59 (quoting THE FEDERALIST No. 25, at 161 (Alexander Hamilton) (Clinton Rossiter ed., 1961). 
authorization. ${ }^{148}$ Beginning in the late 1700 s, the United States began to engage in hostilities without official declarations of war and Congress has relied upon authorizations for the use of force to confer authority in every conflict since World War II. ${ }^{149}$ The War Powers Resolution, enacted in 1973, "expressly envisions that authorizations to use force can serve as the vehicle for the initiation of war by the United States." "The AUMF explicitly states that it is intended to constitute authorization "within the meaning of section 5(b) of the War Powers Resolution."151 Moreover, the broad scope of the AUMF in comparison to prior authorizations indicates Congress's intent to confer authority as broad as that granted during declared wars. ${ }^{152}$ It would therefore be inaccurate to conclude that Congress's decision to authorize force under the AUMF rather than pursuant to an official declaration of war somehow truncates the President's powers or demonstrates that Congress did not really intend to "declare war" against a non-state actor.

Moreover, the various governmental branches have subsequently treated the conflict against al Qaeda as a war. President Bush immediately stated that the attacks qualified as an "armed conflict,", 153 then subsequently described that conflict as a "war." "154 The Supreme Court implicitly upheld the characterization of the attacks as an act of war in Hamdi v. Rumsfeld by recognizing that the AUMF sanctioned the President's execution of the war in Afghanistan. ${ }^{155}$ In addition to enacting clarifying legislation such as the MCA, Congress has appropriated billions for use in the war on terrorism, the detention of suspected terrorists as enemy combatants, and military commissions. ${ }^{156}$

Treating al Qaeda's affiliates as enemy combatants seems a practical implication of the political determination that the attacks qualified as acts

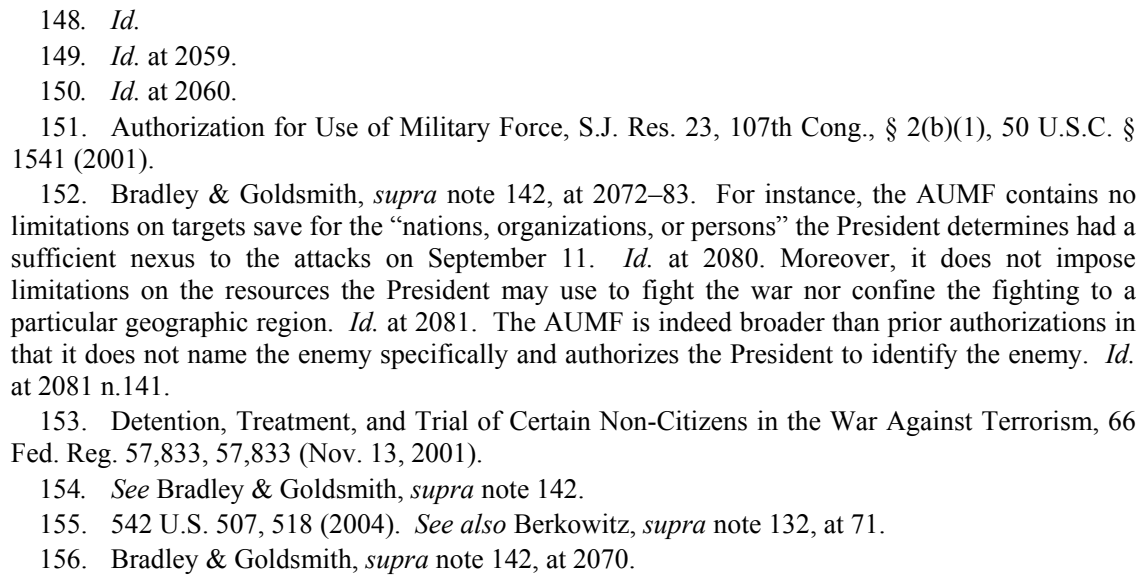

152. Bradley \& Goldsmith, supra note 142, at 2072-83. For instance, the AUMF contains no limitations on targets save for the "nations, organizations, or persons" the President determines had a sufficient nexus to the attacks on September 11. Id. at 2080. Moreover, it does not impose limitations on the resources the President may use to fight the war nor confine the fighting to a particular geographic region. Id. at 2081. The AUMF is indeed broader than prior authorizations in that it does not name the enemy specifically and authorizes the President to identify the enemy. Id. at 2081 n. 141 .

153. Detention, Treatment, and Trial of Certain Non-Citizens in the War Against Terrorism, 66 Fed. Reg. 57,833, 57,833 (Nov. 13, 2001).

154. See Bradley \& Goldsmith, supra note 142 .

155. 542 U.S. 507, 518 (2004). See also Berkowitz, supra note 132, at 71.

156. Bradley \& Goldsmith, supra note 142, at 2070. 
of war. The broad language of the AUMF does not geographically limit the President's authority to detain and therefore certainly seems to encompass "surreptitious al Qaeda agents operating within the continental United States." 157 Judge Motz disagreed, concluding that the legislative history of the AUMF demonstrates Congress intended to provide the President the authority to act abroad but not to detain those within the United States. ${ }^{158}$ This position directly contradicts the language of the AUMF as well as the clear congressional purpose in granting such authority: to reach those similarly situated to the 9/11 actors and thereby prevent the recurrence of another destructive attack. ${ }^{159}$

The power to determine when a state of war exists has been vested in Congress alone. ${ }^{160}$ Judicial interference with such determinations undermines one of the most fundamental principles of our constitutional system: separation of powers. ${ }^{161}$ As once noted by the Supreme Court:

[T] he very nature of executive decisions as to foreign policy is political, not judicial. Such decisions are wholly confided by our Constitution to the political departments of the government, Executive and Legislative .... They are and should be undertaken only by those directly responsible to the people whose welfare they advance or imperil. They are decisions of a kind for which the Judiciary has neither the aptitude, facilities nor responsibility and have long been held to belong in the domain of political power not subject to judicial intrusion or inquiry.

157. Al-Marri II, 487 F.3d 160, 196 (4th Cir. 2007) (Hudson, J., dissenting), vacated en banc per curiam sub nom. al-Marri III, 534 F.3d 213 (4th Cir. 2008).

158. Al-Marri III, 534 F.3d at 239-40 (Motz, J., concurring). Judge Motz recounts that prior to the Senate vote on the AUMF, the administration sought to insert the words "in the United States" after "appropriate force" to provide the President authority not just overseas but also in the United States, potentially against American citizens. Id. The Senate rejected the proposed language. Id. Judge Motz also pointed to the following statement of Senator Biden as evidence Congress did not intend to authorize the detention of those acting from within the United States: "In extending this broad authority to cover those 'planning, authorizing, committing, or aiding the attacks,' it should go without saying, however, that the resolution is directed only at using force abroad to combat acts of international terrorism." Id. (citing 147 Cong. Rec. 17,047 (2001) (statement of Sen. Biden)).

159. See, e.g., Military Commissions Act of 2006, 10 U.S.C. § 948a(1)(A)(i) (2006) (defining an "unlawful enemy combatant" as an individual "who has engaged in hostilities or who has purposefully and materially supported hostilities against the United States or its co-belligerents who is not a lawful enemy combatant (including a person who is part of the Taliban, al Qaeda, or associated forces)").

160. U.S. CONST. art I, § 8, cl. 2.

161. See al-Marri III, 534 F.3d at 294 (Wilkinson, J., concurring in part and dissenting in part) ("[O]ur Constitution is a feat of architecture as well as a charter of cherished rights. To overlook the constitutional allocation of authority to Congress and the President in this case is to replace the Framers' design with our own precarious arrangements.").

162. Chi. \& S. Air Lines, Inc. v. Waterman S.S. Corp., 333 U.S. 103, 111 (1948). 
The power of Congress to declare war must not be subject to a limiting judicial definition of "warfare." As Alexander Hamilton once emphasized, congressional and executive powers must remain flexible in the face of phenomenal changes in warfare:

These powers ought to exist without limitation, because it is impossible to foresee or to define the extent and variety of national exigencies, and the correspondent extent and variety of the means which may be necessary to satisfy them. The circumstances that endanger the safety of the nation are infinite .... This power ought to be coextensive with all the possible combinations of such circumstances; and ought to be under the direction of the same councils, which are appointed to preside over the common defense. ${ }^{163}$

\section{B. Law of War Principles Provide Guidance in Defining and Limiting Combatant Status}

The advent of international terrorism as a form of "armed attack" sufficient to initiate warfare has resulted in a vigorous debate regarding the appropriate classification of culpable individuals under international law. The applicable legal norms were crafted over centuries of warfare between states and thus largely rest upon antiquated assumptions. ${ }^{164}$ Professor Daphné Richemond identifies one of these assumptions as the belief that civilians and combatants fall into clearly distinguishable groups. ${ }^{165}$ In a war against a transnational terrorist organization, the traditional indicia of group membership, like uniforms or open bearing of arms, will not apply, as the "enemy" will intentionally blend into civilian society. The difficulty, then, is in delineating between affiliates of the enemy-"combatants"-and "civilians." The executive and legislative branches have taken the position that mere association with or support to the enemy organization is sufficient to render one an "enemy combatant." $"$ Under this approach, unintentional acts clearly insufficient under traditional norms to confer "combatant" status may result in extended military confinement. A nation committed to the protection of civil liberties must demand a more rigorous standard. In

163. The Federalist No. 23, at 149 (Alexander Hamilton) (Clinton Rossiter ed., 1961).

164. Daphné Richemond describes three assumptions upon which traditional warfare rested: that states alone engage in warfare, that civilians and combatants fall into clearly distinguishable groups, and that parties to a conflict (states) act on the basis of reciprocity. Richemond, supra note 82, at $1002-03$.

165. Id.

166. Military Commissions Act of 2006, 10 U.S.C. $\S 948 a(1)$ (2006). 
order to determine the proper approach, the following section will consider the historical basis for distinguishing between combatants and civilians. It will then analyze how states have distinguished between combatants and civilians in practice as a basis for establishing principled limits upon the application of the "enemy combatant" label to suspected terrorists.

1. The Historical Rationales for Distinguishing Combatants from Civilians Support Classification of Al Qaeda Members as Combatants

The distinction between combatants and civilians pre-existed the Geneva Conventions. Several ancient legal codes prohibited the targeting of women or children and sought to distinguish between "soldiers" and "others." 167 Esteemed writers such as Francisco de Vitoria and Hugo Grotius - the father of modern international lawlikewise espoused the need for distinction. ${ }^{168}$ In 1863, the American jurist Francis Lieber drafted the influential Lieber Code-a guide for determining who qualified as an "ordinary belligerent" during the Civil War. ${ }^{169}$ Lieber insisted upon the protection of the "inoffensive individual," the unarmed citizen. ${ }^{170}$ The Lieber Code's distinction between combatants and noncombatants served as the basis for later twentieth century codifications: "“[a]ll enemies in regular war are divided into two general classes - that is to say, into combatants and noncombatants, or unarmed citizens of the hostile government.",171

The historical foundation for distinguishing between combatants and civilians stemmed from the idea that certain persons are presumed innocent and thus should not be targeted. ${ }^{172}$ For instance, Francisco de

167. Richemond, supra note 82, at 1017. For instance, the Chinese distinguished between "soldiers" and "people" and the Old Testament urged soldiers "to spare women and children." Id. The Hellenes understood "that the guilt of war is always confined to a few persons and that the many are their friends" "and were to refrain from assuming that "the whole population of a citymen, women, and children-are equally their enemies." Id. at 1017-18 (quoting 1 LEON FRIEDMAN, THE LAW OF WAR 5 (1972)).

168. Id. at 1018 .

169. Id. at 1018-20. Lieber drafted the Code for General Henry Wager Halleck, General-inChief of the Union Armies during the Civil War. Halleck commissioned the Code "because he was confused about who could be considered an 'ordinary belligerent,' and worried about the consequences of capture for his own men." Id. at 1019.

170. Id. at 1019 .

171. Id. at 1019-20 (quoting Instructions for the Government of Armies of the United States in the Field, art. 155, Apr. 24, 1863, available at http:/www.icrc.org/ihl.nsf/FULL /110?OpenDocument [hereinafter Lieber Code]).

172. Id. at 1027 . 
Vitoria stated "“[I]t is never lawful in itself intentionally to kill innocent persons.... It follows that... we may not kill children, who are obviously innocent, nor women, who are to be presumed innocent.",173 However, even Vitoria recognized that an innocent person could become a legitimate target when he took up arms. ${ }^{174}$ In other words, the determinative point at which one could be deemed a "combatant" was when he took up arms against the enemy. ${ }^{175}$ As discussed below, this concept has not only been interwoven into the practice of states in warfare, but has also been incorporated into modern treaties on warfare. Similarly, this concept may serve as a distinguishing factor in determining combatant status even in unconventional warfare against stateless actors. In particular, those associated with the enemy organization may be deemed combatants or non-combatants depending upon the degree to which such individuals have actively engaged in hostilities in contravention of international norms. ${ }^{176}$

\section{State Practice and the "Laws of War" Confirm that Civilians}

Actively Engaging in Hostilities Qualify as Combatants

Association has traditionally served as the primary indicator of combatant status. Thus, all residents of the hostile nation were deemed "enemies" during warfare while combatant status relied primarily upon one's membership in the armed forces. ${ }^{177}$ This traditional conception of combatant status led to the position espoused in al-Marri II that the only individuals capable of qualifying as "unlawful combatants" are otherwise lawful combatants who have lost their privilege to engage in warfare by violating the laws of war. ${ }^{178}$ Under this interpretation, individuals may be deemed "unlawful combatants" only when affiliated with the "military arm" of a recognized government. Although such individuals

173. Id. at 1028 (quoting Francisco de Vitoria, On the Law of War, in POLITICAL Writings 293, 314-15 (Anthony Pagden \& Jeremy Lawrance eds., 1991)).

174. Id.

175. Id.

176. See id.

177. Al-Marri III, 534 F.3d 213, 316 (4th Cir. 2008) (Wilkinson, J., concurring in part and dissenting in part) (citing Ex parte Quirin, 317 U.S. 1, 30-31 (1942); Lamar v. Browne, 92 U.S. 187, 194 (1875); In re Territo, 156 F.2d 142, 145 (9th Cir. 1946)).

178. See al-Marri II, 487 F.3d 160, 186 (4th Cir. 2007), vacated en banc per curiam sub nom. al-Marri III, 534 F.3d 213 ("To be sure, enemy combatants may commit crimes just as civilians can. When an enemy combatant violates the law of war, that conduct will render the person an unlawful enemy combatant, subject not only to detention but also to military trial and punishment."); al-Marri III, 534 F.3d at 235 (Motz, J., concurring) ("[M]erely engaging in unlawful behavior does not make one an enemy combatant."). 
certainly qualify as "unlawful combatants," "179 the laws of war have long recognized that an individual may be deemed an "unlawful belligerent" even when unaffiliated with the military forces of the enemy state. ${ }^{180}$

An international treatise written during the Second World War explained when this may occur:

Private individuals who take up arms and commit hostilities against the enemy do not enjoy the privileges of armed forces, and the enemy has, according to a customary rule of International Law, the right to treat such individuals as war criminals. But they cease to be private individuals if they organize themselves in a manner which, according to the Hague Convention, confers upon them the status of members of regular forces.

The United States has also engaged in the practice of treating civilians as "unlawful combatants" based upon their active participation in hostilities. During the Civil War, the instructions for Union Soldiers regarding the treatment of individuals who engaged in belligerency without the privilege to do so were as follows: "[m]en, or squads of men, who commit hostilities... without being part and portion of the organized hostile army, and without sharing continuously in the war, ... if captured, are not entitled to the privileges of prisoners of war, but shall be treated summarily ...." ${ }^{\prime 182}$ Nearly one hundred years later, the United States Military Tribunal at Nuremburg stated that "'the rule is established that a civilian who aids, abets or participates in the fighting is liable to punishment as a war criminal under the law of wars. Fighting is legitimate only for the combatant personnel of a country.""183

The Geneva Conventions implicitly embraced the distinction between lawful and unlawful combatants, ${ }^{184}$ as well as the idea that civilians may become "unlawful combatants" by actively engaging in hostilities. For instance, Geneva Convention IV excludes certain

179. In re Yamashita, 327 U.S. 1, 11 (1946).

180. Owen Fiss, Law is Everywhere, 117 YALE L.J. 256, 265 (2007); Jean-François Quéguiner, Direct Participation in Hostilities Under International Humanitarian Law 8-9 (Program on Humanitarian Policy \& Conflict Research at Harvard Univ., Working Paper, 2003), available at http://www.ihlresearch.org/ihl/pdfs/briefing3297.pdf; Lee A. Casey, David B. Rivkin, Jr., \& Darin R. Bartram, Unlawful Belligerency and its Implications Under International Law (2005), http://www.fed-soc.org/publications/pubID.104/pub_detail.asp.

181. Casey et al., supra note 180 (citing 2 LASSA OPPENHEIM, INTERNATIONAL LAW 454 (6th ed. 1940)).

182. Lieber Code, supra note 171, art. 82.

183. Quéguiner, supra note 180 , at 10 n.40 (quoting UNITED NATIONS WAR CRIMES COMMISSION, LAW REPORTS OF TRIALS OF WAR CRIMINALS 111 (1997)).

184. Casey et al., supra note 180. 
individuals from enjoying the full protections accorded civilians-or "protected persons":

Where, in the territory of a Party to the conflict, the latter is satisfied that an individual protected person is definitely suspected of or engaged in activities hostile to the security of the State, such individual person shall not be entitled to claim such rights and privileges under the present Convention as would, if exercised in the favour of such individual person, be prejudicial to the Security of such State.

Article 5 proceeds to list the minimal rights to be afforded such individuals:

In each case, such persons shall nevertheless be treated with humanity, and in case of trial, shall not be deprived of the rights of fair and regular trial prescribed by the present Convention. They shall also be granted the full rights and privileges of a protected person under the present Convention at the earliest date consistent with the security of the State .... ${ }^{186}$

The drafters of the Convention inserted Article 5 to address the status of civilians who directly participated in hostilities. They did not want to provide such individuals with the full protections accorded to prisoners of war as they failed to comply with the requirements for such status. ${ }^{187}$ Nor did the drafters want to afford such individuals with the protections provided to innocent civilians as they had violated the laws of war by engaging in combat without privilege to do so. ${ }^{188}$ For example, the British delegate stated that the Civilian Convention was intended to protect "civilian victims of war" and not to protect "illegitimate bearers of arms, who could not expect full protection under rules of war to which they did not conform." 189 The delegate from the International Committee of the Red Cross (ICRC) noted that the Conventions did not protect irregular belligerents, as it was uncertain whether " "persons who did not conform to the laws and customs of war" "should be provided protection, but that the drafters inserted Article 5 nonetheless to accord minimal protection and thus prevent the summary execution of such individuals. ${ }^{190}$ Therefore, the laws of war relating to international armed

\footnotetext{
185. Geneva Convention IV, supra note 64, art. 5 (emphasis added).

186. Id.

187. Dörmann, supra note 66, at 53.

188. Id.

189. Id at 53 n.19 (quoting 2A FinAl ReCORD OF THE Diplomatic CONFERENCE OF 1949, at

190. Id. at 53 (quoting 2A FinAl RECORD OF THE Diplomatic CONFERENCE OF 1949, at 433).
} $621)$. 
conflict clearly delineate between combatants and civilians not only based on the affiliation of such individuals with the military branch of the enemy state but also, in the absence of such affiliation, whether the individuals have impermissibly engaged in hostile acts.

The Supreme Court's determination that the war against al Qaeda qualifies as "non-international" raises questions more technical than substantive in form regarding whether civilians engaging in hostilities in a non-international armed conflict may also be deemed "unlawful combatants." In 2005, the ICRC published an official statement espousing the view that, in non-international armed conflicts, combatant status simply does not exist. ${ }^{191}$ In holding that al-Marri could not qualify as a combatant, the panel majority accepted this statement as authoritative. ${ }^{192}$ However, Common Article 3 to the 1949 Geneva Conventions and the related commentary demonstrate that even in noninternational armed conflicts, an individual may be considered a combatant if he directly participates in hostilities. Common Article 3 distinguishes between those taking an active part in hostilities and those not doing so: "Persons taking no active part in the hostilities ... shall in all circumstances be treated humanely...." "193 The protections of Common Article 3 therefore apply only to those "taking no active part in hostilities."194 In addition, Common Article 3 applies to "armed conflicts, with armed forces on either side engaged in hostilities" notion of "armed conflict" necessarily implying the existence of combatants. The proposition that a civilian engaging in hostilities may be deemed a combatant even in a non-international armed conflict is supported by the historical purposes for distinguishing between combatants and civilians: to protect the innocent and punish those engaging in warfare without privilege to do so.

The "active participation in hostilities" standard should assist in guiding the determination of whether suspected terrorists qualify as "combatants." Of course, because the nature of warfare has changed, the classification must no longer rely upon "quaint and out-moded" concepts such as enemy states, residency, and "demarcated foreign battlefields." 196

\footnotetext{
191. Int'L Comm. OF THE Red CRoss, OfFicial Statement: THE Relevance OF IHL IN THE CONTEXT OF TERRORISM (Feb. 21, 2005), http://www.icrc.org/Web/Eng/siteeng0.nsf/htmlall /terrorism-ihl-210705.

192. Al-Marri II, 487 F.3d 160, 185 (4th Cir. 2007), vacated en banc per curiam sub nom. alMarri III, 534 F.3d 213 (4th Cir. 2008).

193. Geneva Convention IV, supra note 64, art. 3 .

194. Id.

195. Geneva Conventions Commentary, supra note 77.

196. Al-Marri III, 534 F.3d at 293 (Wilkinson, J., concurring in part and dissenting in part).
} 
Nonetheless, the traditional treatment of actively hostile civilians during warfare demonstrates that the focus of classification in unconventional situations should be not merely upon the conventional "associational" aspect, but more importantly, upon the individual's relevant conduct.

3. Direct Participation in Hostilities Encompasses Espionage and Preparation for Acts of Sabotage

Since September 11, the question of whether terrorist acts can qualify as "direct participation in hostilities" has been vigorously debated within the international community. ${ }^{197}$ The ICRC has hosted meetings of experts from around the globe to consider the precise meaning of the standard. ${ }^{198}$ Interestingly, the ICRC noted in its report that no opposition was expressed to the idea that intelligence gathering could constitute a direct participation in hostilities. ${ }^{199}$ Other commentators have insisted that the phrase "hostilities" has commonly been interpreted as encompassing preparation for attack. ${ }^{200}$ Any activities undertaken in preparation for future attacks should therefore qualify as "participation" in hostilities, sufficient to confer "unlawful combatant" status.

\section{A Proper Balance}

Based on the principles and standards discussed in Part III, the term "enemy combatant" should be defined to include:

(a) An individual who qualifies for prisoner of war status under the Third Geneva Convention; or

(b) An individual who does not qualify for prisoner of war status under the Third Geneva Convention but who

1. Is affiliated with a state or organization against which the United States is engaged in an authorized armed conflict;

2. Engages in, aids and abets, or prepares to commit hostile acts against the United States or its co-belligerents; and

\footnotetext{
197. See, e.g., INT'L COMM. OF THE REd CROSS, DiReCt PARTICIPATION IN Hostilities UNDER INTERNATIONAL HUMANITARIAN LAW (2003), available at http://www.icrc.org/Web/eng /siteeng0.nsf/htmlall/participation-hostilities-ihl-311205 (scroll down and follow "Summary report 2003" hyperlink) (tracking the debate among experts attending the meeting).

198. See id. at 2.

199. Id. at 3 .

200. Richemond, supra note 82, at 1022.
} 
3. Acts with the intent thereby to harm the nation, its civilians, its economy, or its national security.

An individual qualifying for prisoner of war status under the Geneva Convention III (a lawful combatant) may properly be subject to military detention until the end of hostilities pursuant to traditional international standards. The individual, however, may not be tried by a military tribunal for his acts of hostility unless he has committed a violation of the laws of war. An "unlawful enemy combatant," or one who has engaged in hostilities without the privilege to do so, may be subject to military detention and trial for those acts which render his belligerency unlawful. $^{201}$

\section{The Proposed Definition Comports with Due Process Standards}

Regardless of the ever-increasing levels of technological sophistication in warfare, a challenge, as old as warfare itself, remains for every civilized state: how are civil liberty interests to be weighed visà-vis the need for order and military victory? Due to political exigencies, the government has greater authority in time of war to engage in conduct potentially infringing upon civil liberties. ${ }^{202}$ It is the primary responsibility of the state to ensure the security and well-being of its inhabitants. Yet civil liberties must not be permitted to erode to the point of jeopardizing the very freedoms upon which the political identity of the state is built. Therefore, the proper parameters for the term "enemy combatant" must hinge not only upon the breadth of authority provided the executive to militarily detain suspected terrorists, but also upon whether the Constitution permits the executive to undertake such detentions. ${ }^{203}$ The following section addresses these concerns by exploring the rights owed to lawful residents or citizens of the United States during peace and when such rights may be deprived to ensure state security. In addition, it will highlight the elements of the proposed definition ensuring continued adherence to the protection of essential individual liberties.

\footnotetext{
201. Ex parte Quirin, 317 U.S. 1, 30-31 (1942).

202. REHNQUIST, supra note 1, at 218.

203. Al-Marri III, 534 F.3d 213, 296 (4th Cir. 2008) (Wilkinson, J., concurring in part and dissenting in part).
} 
1. Recognized Derogations from the Protections of the Due Process Clause Support the Detention of Al Qaeda Operatives Working Surreptitiously Within the United States

The Due Process Clause of the Fifth Amendment prohibits the government from depriving any person of liberty without due process of law. ${ }^{204}$ The Supreme Court has long recognized that "[f]reedom from imprisonment - from government custody, detention, or other forms of physical restraint - lies at the heart of the liberty that Clause protects." ${ }^{205}$ The Fifth Amendment protection of "persons" extends to all those who have entered the United States and developed substantial connections within, regardless of whether they initially entered lawfully. ${ }^{206}$

Yet the liberty interest protected by the Due Process Clause is not absolute. Important derogations have long been recognized in the interest of community safety. ${ }^{207}$ Therefore, the mentally ill may be civilly committed and recidivist sex offenders unable to control their criminal tendencies may be confined. ${ }^{208}$ Similarly, in times of military necessity, those qualifying as "enemy combatants" may be detained for the duration of hostilities. ${ }^{209}$ Prior to the September 11 attacks, the Supreme Court recognized that terrorist activity could qualify as a "special circumstance," where arguments "might be made for forms of preventive detention and for heightened deference to the judgments of the political branches with respect to matters of national security." 210

The "combatant exception" to the due process requirement traditionally applied to those acting on behalf of a sovereign nation. However, the decision of Congress that al Qaeda affiliates qualify as

204. U.S. CONST. amend. V.

205. Zadvydas v. Davis, 533 U.S. 678, 690 (2001) (citing Foucha v. Louisiana, 504 U.S. 71, 80 (1992)).

206. United States v. Verdugo-Urquidez, 494 U.S. 259, 271 (1990) (explaining that aliens are entitled to the protections within the Due Process Clause when they "have come within the territory of the United States and developed substantial connections with the country."); Matthews v. Diaz, 426 U.S. 67, 77-78 (1976) ("Even one whose presence in this country is unlawful, involuntary, or transitory is entitled to that constitutional protection.").

207. Kansas v. Hendricks, 521 U.S. 346, 356-57 (1997).

208. Id. at 358 .

209. Hamdi v. Rumsfeld, 542 U.S. 507, 516 n.1 (2004).

210. Zadvydas, 533 U.S. at 696. In Zadvydas, the Court considered whether the Attorney General may indefinitely detain aliens who have already been ordered removed from the United States. Id. at 682. After recognizing that a statute authorizing indefinite detention of aliens would "raise serious constitutional concerns," the Court interpreted the relevant statute as containing a reasonable time limitation. Id. Moreover, the Court insisted that the application of the reasonable time limitation be subject to review by the federal courts. Id. The Court distinguished the situation it faced from that presented by dangerous terrorists. Id. at 695-96. 
"combatants" is a constitutionally permissible exercise of its exclusive authority to declare the existence of hostilities. Deference to this determination, as well as to the realities of modern warfare, requires an extension of the "combatant" exception to individuals actively engaging in hostile activity on behalf of such an organization. This conclusion is supported by the Supreme Court's position that terrorism could justify the preventive detention of demonstrably dangerous individuals such as al-Marri.

Detainees are nonetheless entitled to certain procedural protections. A detainee must be provided "notice of the factual basis for his classification, and a fair opportunity to rebut the Government's factual assertions before a neutral decisionmaker." 211 A military tribunal may satisfy the "neutral decisionmaker" requirement. ${ }^{212}$ However, combatant detainees are entitled to judicial review of the grounds for detainment through a petition for a writ of habeas corpus. ${ }^{213}$ Such procedural protections help to ensure that the detention of suspected terrorists will not result in indefinite confinement of innocent individuals.

2. The Proposed Definition Permits the Executive to Ensure "Community Security" and Prevents Unjustifiable Intrusion upon Civil Liberties

The precise contours of the proposed definition ensure a satisfactory balance between the security needs of the state and the protection of civil liberties. By treating hostile al Qaeda members as "combatants," the definition eliminates the risks inherent in applying a reactive policing model to suspected terrorists and recognizes that the "battlefield" in modern warfare extends beyond the area of active combat operations. The definition simultaneously prevents the encroachment of the military upon cherished civil liberties. The key components include the following: (a) affiliation with an organization (b) with which the United

211. Hamdi, 542 U.S. at 533. Hamdi addressed the status of a citizen detainee; however, lawful resident aliens should enjoy the same protections, particularly given the potential for executive overreaching and faulty determinations.

212. Id. at 538. The military tribunal may permit hearsay evidence and the government may be entitled to an evidentiary presumption. Id. at 533-34.

213. See Boumediene v. Bush, 128 S. Ct. 2229, 2262, 2274 (2008) (holding that "enemy combatants" detained in Guantánamo Bay, Cuba, are entitled to petition for a writ of habeas and that Congress in enacting the Military Commissions Act unconstitutionally attempted to suspend the writ in relation to such individuals); Ex parte Quirin, 317 U.S. 1, 23-25 (1942) (upholding judicial review over the jurisdiction of military commissions established to try enemy saboteurs captured on U.S. soil, even though a presidential proclamation had attempted to strip the courts of habeas review). 
States is engaged in an authorized armed conflict, and (c) actual engagement in or preparation for hostilities.

\section{a. Affiliation}

An Argentine general allegedly once declared: "First we will kill all of the terrorists; then we will kill all who helped them, and then we will kill all who did not help us." ${ }^{214}$ The affiliation requirement ensures that the military detention of a few, culpable individuals will not result in the general's infamous slippery slope. It serves as the functional equivalent of the traditional "residency" element of combatant status in this new form of warfare against a stateless actor. ${ }^{215}$ It prevents the military detention of domestic "criminals," such as Timothy McVeigh, as well as the increasing number of homegrown extremists inspired by but not affiliated with al Qaeda or a similar terrorist organization. ${ }^{216}$ Although independent, self-proclaimed terrorists certainly pose a threat to state security, ${ }^{217}$ the threat from such individuals is "vastly different" than that from individuals directed and funded by al Qaeda because of al Qaeda's superior attack capabilities. ${ }^{218}$ Moreover, the detention of those unaffiliated with al Qaeda or a terrorist organization demonstrably linked to al Qaeda cannot fall within the scope of authority granted under the AUMF as a necessary incident to the authorized use of force. ${ }^{219}$ The affiliation requirement therefore serves a vital function in limiting the scope of detentions permitted and may, as Judge Wilkinson suggested in al-Marri III, be effectuated by requiring such indicators as selfidentification or participation in hostile activities on behalf of the organization. ${ }^{220}$

214. Tom J. Farer, The Two Faces of Terror, 101 AM. J. INT'L L. 363, 365 (2007)

215. See al-Marri III, 534 F.3d 213, 314-15 (4th Cir. 2008) (Wilkinson, J., concurring in part and dissenting in part).

216. After the attacks on September 11, the threat of terrorism has increasingly turned toward homegrown extremists acting without any direction from al Qaeda; therefore, militant terrorism has begun to dissipate from the central al Qaeda core, resulting in "less defined networks of extremists." Mueller statement, supra note 23.

217. Id.

218. Id.

219. See Hamdi v. Rumsfeld, 542 U.S. 507, 518 (2004) (permitting the detention of enemy combatants pursuant to the "necessary and appropriate" force authorized by Congress).

220. Al-Marri III, 534 F.3d at 315 (Wilkinson, J., concurring in part and dissenting in part). 
b. The United States Must be Engaged in an Authorized Armed Conflict with the Organization

Congress has authorized the use of force against "those nations, organizations, or persons" responsible for the attacks on September 11. ${ }^{221}$ It certainly did not authorize the use of force against any and all transnational terrorist organizations. Unfortunately, the executive seems not to have considered its authority under the AUMF to be so limited. The following statement made by President Bush on September 20, 2001, is illustrative: "Our enemy is a radical network of terrorists, and every government that supports them. Our war ... begins with al Qaeda, but it does not end there. It will not end until every terrorist group of global reach has been found, stopped, and defeated." ${ }^{, 22}$ Such sweeping assertions of authority have justifiably led to scholarly concern of executive overreaching and the seemingly limitless scope of the "war on terror." 223 However, the AUMF contains a principled limitation upon the detention of extremists by narrowing the scope of permissible military force, and thus detention, to that used against organizations responsible for the September 11 attacks - namely, al Qaeda. Judge Wilkinson, in al-Marri III, similarly espoused an "authorization" requirement, recognizing that it is "both consistent with our traditional conception of who should and should not be eligible for detention and appropriate in light of the constitutional imperative that military detention be the exception and not the rule." 224

Limiting the application of the enemy combatant label to those affiliated with an organization against which Congress has authorized the use of force serves another important purpose: it helps to conceptualize an end to the hostilities. Traditionally, a combatant could be detained for the length of hostilities, to prevent his return to the battlefield. ${ }^{225}$ One of the most disconcerting aspects of the "war on terror" is its seemingly indefinite nature. By limiting the military response to al Qaeda and its affiliates, identification of the "enemy" is achieved and an end to the hostilities foreseeable.

221. Authorization for Use of Military Force, S.J. Res. 23, 107th Cong., 50 U.S.C. $§ 1541$ (2001).

222. President George W. Bush, Address to a Joint Session of Congress and the American People (Sept. 20, 2001) (transcript available at http://www.whitehouse.gov/news/releases/2001 /09/20010920-8.html).

223. Bradley \& Goldsmith, supra note 142, at 2050.

224. Al-Marri III, 534 F.3d at 323 (Wilkinson, J., concurring in part and dissenting in part).

225. Hamdi v. Rumsfeld, 542 U.S. 507, 520-21 (2004). 
c. The Individual Must Have Intentionally Engaged in or Prepared for Hostilities

By requiring that the individual have intentionally engaged in or prepared for hostilities, the definition furthers the purposes behind the distinction between combatants and civilians. In particular, it prevents the detention of the truly innocent and protects the sanctity of combatant immunity by penalizing those who engage in hostilities without the right to do so. This participation requirement ensures that mere membership is insufficient to confer combatant status, requiring the government to demonstrate activity in furtherance of the organization's military goals.

The participation requirement contrasts sharply with the treatment of suspected terrorists pursuant to the Military Commissions Act. The MCA defines an "unlawful enemy combatant" as any individual who has "purposefully and materially supported hostilities.",26 As observed by scholar Jordan J. Paust, "[o]ne who merely materially supports hostilities is not a fighter or combatant."227 For example, the standard could encompass an individual who unwittingly makes a monetary contribution to a terrorist organization, ${ }^{228}$ or a cleric who incites violence through political writings or speeches. ${ }^{229}$ The detention of such individuals deviates substantially from international norms relating to the detention of civilians, emphasizing intentional and active participation, and therefore should not be permissible. On the other hand, the detention of active participants conforms to the innocence-based notion of civilian status currently expressed in international law and supported by the practice of states. It therefore successfully balances the traditional rationales behind combatant status and immunity with the realities of modern warfare.

\section{CONCLUSION}

The traditional judicial conception of an "enemy combatant" must be modified so as to encompass all individuals engaging in or preparing for hostile activities on behalf of organizations against which Congress has authorized the use of force. This approach properly defers to the determination of Congress that the attacks on September 11 initiated a state of warfare between the United States and a nontraditional actor

226. Military Commissions Act of 2006, 10 U.S.C. § 948a(1)(A)(i) (2006).

227. Paust, supra note 140 , at 777 .

228. 152 Cong. Rec. E1909 (daily ed. Sept. 29, 2006) (statement of Rep. Schakowsky).

229. Hass, supra note 75, at 1120. 
while simultaneously ensuring that detention occurs only within permissible constitutional bounds. The proposed definition also conforms to the historical purposes for delineating between combatants and civilians by emphasizing not only the conventional indicia of combatant status-association-but also the degree to which the individual has engaged in belligerent conduct. Finally, it prevents excessive military intrusion into civilian society by requiring congressional oversight of the scope of permitted detentions pursuant to a customary authorization of force. Although warfare always creates an alarming potential for governmental overreach and unwarranted encroachments upon civil liberties, the proposed definition reduces the persuasive force of such concerns by achieving what Chief Justice Rehnquist termed the "most important task" of our society: a proper balance between freedom and order. ${ }^{230}$ 